\title{
Ahmad bay Aghaoglu's Activity in Literary and Cultural Criticism
}

\author{
Madina Karahan \\ Khazar University, Baku, Azerbaijan \\ medina.karahan@gmail.com
}

\begin{abstract}
Ahmad Bay Aghaoglu played a significant role as a public figure, publicist, politician, lawyer, scientist, and intellectual in the literary and public thoughts and the political life of the history of 20th century of our country. His activity and works had a great impact on the public processes in Azerbaijan and Turkey, as well as Europe.

In the activity of A.Aghaoglu, his literary and scientific works have an important place; i.e. he has also historical and literary essays in addition to his works dedicated to socialpolitical issues, which characterizes him as a critic, literary critic and culturologist. His addressing to literary and scientific issues as the occasion arises in many of his works, articles, letters and memoirs and opening discussions enables us to assess him as a critic, literary critic, historian and sociologist in the literary environment of Turkey.

The Thesis studies the issues that Ahmad Bay Aghaoglu researched as a researcher, literary critic and historian, and the printed works covering these issues, and expresses an opinion.
\end{abstract}

Keywords: Ahmad Bay Aghaoglu, Public Figure, Criticism and Literary Criticism, Russian Literature, National History of Literature

\section{Introduction}

A. Aghaoglu started his activity as a critic and literary critic when he yet lived in Azerbaijan. Those works were dedicated to the Azerbaijani literature and the works of its various representatives. With respect to his research works of that time, professor K.Talibzadeh writes by referring to his article titled Shakespeare's Othello and Schiller's Robbers in Tatarian: 'The Article was written with the aim to produce the best examples of the classic dramaturgy in the scene of Azerbaijan. The Author interprets this important cultural event as one of the 'novelties' running 'in flamy dreams', and mentions the significant cognitive importance of the 
creation of an opportunity by such translations and spectacles to Azerbaijani readers and listeners to get familiar with the achievement of the European literature' (Kamal, 1989, pp. 135-146)

The interesting thing is that in this Article, A.Aghaoglu not only analyzes the spectacles of Othello and Robbers, but also refers to the Azerbaijani literature as the occasion arises, and makes comparisons. And his expressing his thoughts and ideas about M.F.Akhundzadeh's work titled Haji Gara, N.Vazirov's work titled From the rain to shower, and A.Hagverdiyev's work titled Broken Nestle in that Article also confirms our thought. It is observed that the writer has a certain literary worldview in his articles related to the Russian literature. In all of his these articles, it becomes clear that A.Aghaoglu is one of the experts of both the Oriental and Western literatures.

\section{View to Aghaoglu's inquiry based works}

One of A.Aghaoglu's works, which is a research, reflecting his activities in the spheres of criticism, literary criticism and culturology is his work titled 'General Characteristics of Russian Literature', written in Turkey. The writer wrote that work in 1917. However, until that work, the writer also used to frequently refer to the works of various representatives of the Western and Oriental literatures in his other works to express his opinions. And in his works before the period of Turkey, his articles dedicated to particularly the Russian literature and various writers were published in newspapers of Azerbaijan, such as Kafkaz, Kaspi, Hayat, Irshad, Taraggi and Progress. And even after leaving for Turkey, the writer-publicist continued his researches in that regard. In general, A.Aghaoglu regularly followed up the Russian literature and social process since the time when he came to the social environment. The researches he conducted in that regard and his writing articles about classics of Russian literature and the writers and poets having a significant place in the history of Russian literature even after leaving for Turkey also confirms our opinion. In particular, his serving as a professor of Russian Language and Literature at Istanbul University resulted in the writing of such a work that is a research. It seems that the publicist and researcher intended to create that work in the form of a lecture, and only in 1932, he improved the research and published it as serial articles (five articles) on Jumhuriyat Newspaper. According to Researcher V. Gouliyev, who prepared A.Aghaoglu's Selected Works for publication: 'Surely, they were based on the materials of the course 'History of Russian Literature' that A.Aghaoglu taught at Istanbul University.' (Vilayet, 2007, pp. 3-15). If we further clarify this opinion of Literary Critic V.Gouliyev, we can 
say that this research is also based on the articles that he wrote in Azerbaijan. However, the years passed, the fact that A.Aghaoglu gave lectures of this subject in Turkey, and the subsequent development of the Russsian literary criticism brought some scientific nature to the analyzes of the researcher. Sometimes his making comparisons between the Russian literature and the Turkish literary-artistic thought also completes the sum of ideas of the researcher on these literatures.

Kamal Talibzadeh, who evaluated the work 'General Characteristics of Russian Literature' for the first time in the literary criticism of Azerbaijan writes: 'In this research work written with a great respect to the Russian literature, there are also original, subjective views in addition to the considerations that are specific for the official Russian literary criticism and criticism, which need a special professional analysis.' (Kamal, 1989, p. 145)

Surely, when writing this research work, A.Aghaoglu made some references to the works of Russian literary critics, but the fact that the writer had a thorough knowledge of the Russian literature and referred to various literary works show that besides having a thorough knowledge of the Russian literature, the researcher also has an ability to make accurate and objective assessments. In this respect, the work 'General Characteristics of Russian Literature' attracts the attention not only from the theoretical point of view, but also as a rich source for research.

A.Aghaoglu's work 'General Characteristics of Russian Literature' is a brief summary. Although this briefness, the researcher accurately determines the development trends of the Russian literature and objectively assesses its stages, events, the works of its personalities, and the literary process. Showing the vitality as the key character of the Russian literature, the author writes: 'In no nation, the literature proceeded on its way in parallel to the life as much as it did it in the Russians. This direction of the literature was so fitted to the Russian mentality that when Russian literature theorists described the literature, they characterized it as the mirror of the life and atmosphere in general. And really, the history of Russian literature is the history of Russian culture. All trends of the time and all signs of the environment reflected in the literature: it is possible to track the political, social, philosophical, literary, mental and emotional trends in the literary works.' (Ahmad, 1989, p. 147)

\section{About the periods and problems of Russian literature}

In addition to providing encyclopaedic information on the Russian literature and evaluating its stages and the specificity of the works of its personalities, 
A.Aghaoglu's works also research the general development trends of the literature. Calling the prominent representatives of the Russian literature, such as Dostoyevski, Tolstoi and Gorky a school, the researcher searches for the reasons for the becoming of this literature of the global standard. Throughout the work, the researcher prefers to emphasize the factors forming this character of the Russsian literature. He mentions that among these factors, the Russian national conscience has also a share, and concludes that the Russian literature: '....an opportunity to really saw the grradual formation of the Russian national conscience arises..' (Ahmad, 1989, p. 148)

When researching the nature of the Russian literature, A. Aghaoglu draws the attention to its having realist and naturalist descriptions for its nature, and finds this creativity method more specific, as the power of realism was regarded more specific for the Russian literature exactly. The power of realism is in this he describes '...Russia as it is', 'with all its appearances', with its 'most unpleasant and dark' aspects, but maintaining 'a strong balance'. An endless love to the nation 'generates hate', 'rage' to the negative aspects of the life of the nation. This rage and hate originate from the love. (Ahmad, 1989, p. 150).

In the work, the researcher also emphasizes the direction of idealism of the Russian literature, combines 'the idealism and optimism with the saddest aspects of the life', and gives an idealist essence 'to a weak issue'. He thinks, this feature of the Russian literature brings a color of mysticism to it in some way. Exactly as a result of this, Russian writers see that there is a divine feast shining in even a person fallen into the lowest position and indoctrinate this sense to their readers. This feature predominates from Pushkin's and Tolstoi's works describing noble and elite families to Gorky's Ex Men (Ex Hommes) and Bottom (Le Bosfond) works describing the lives of vagrants who already passed all the stages of collapse.' (Ahmad, 1989, p. 151).

When researching the Russian literature, A. Aghaoglu also pays attention to its stages and problems, besides its essence and nature, which shows that the researcher had a certain view with regard to these problems of the Russian literature. Besides not being inattentive to the classifications of Russian literary critics, he also makes his additions to these classifications and ensures the completeness of literary development through this. It is known that early the 20th century, Russian literary critics used to divide it into three periods: The first period lasts up to the 10th century - the period when the Russians adopted the christianity and the first script together with the christianity; The second period lasts from the 10th century to the time of Pushkin; and The third period is the period after Pushkin. But A. Aghaoglu gives the periods in a further simplified form. He calls 
this direction of his research as 'the first periods of Russian literature'. Within the framework of this period, examples of Russian verbal folk literature (bilinas, sagas (Saga about Igor's Regiment), church literature, travel books and etc. are described. It is interesting that when talking about the bilinas, the author also mentions the influence of Tatarian legends to the Russian literature and confirms the view that the characters in Russian sagas are entitled with the name of Bogatir (Bahadir). Here, the researcher also expresses his opinion with regard to the view of such scientists as V. P. Stasov, G. N. Potanin and V. F. Miller, stating that all Russian sagas are excerption from Tatarians. Among the researchers thinking contrarily to this, the author mentions the name of Pipin, as A. N. Pipin accepted the Tatarian influence, but tried to prove that those sagas were independent. A. Aghaoglu specially mentions that among these sagas, The Saga about Igor's Regiment is widely represented in Russian schools, and states that: 'About this poetic saga, so many scientific works that may form a large library have been written. This work originated exclusively from the great talent of the nation bears in a primitive form even at that time all the characters that the Russian literature gained in the future.' (Ahmad, 1989, p. 151).

As the second period of the Russian literature, A.Aghaoglu takes the period lasting from the 10th century to the 19th century and also divides it into three stages by referring to Russian authors: 1 . The Kiev chapter - until the Tatarian occupation, i.e. the 12th century; 2. The Moscow stage - continues until the collapse of Tatars; 3.The renovation and renaissance stage - from the 17 th century until Pushkin's time. Each of these stages is assessed in the research work. Referring to many travel books and facts related to this period, the researcher then gives wide details not reflected in the history of literature. With regard to the Moscow stage, he draws the attention to the correspondences of A. M. Kurbski, a Russian officer, translator, the author of the work 'History about the Grand Moscow Prince' and Ivan Grozny: 'Ivan states in his letters that 'Moscow is the third Rome. The first Rome betrayed to the original and genuine religion. Therefore, it was damned by God. The second Rome is Istanbul, where the genuine religion was born again. However, Istanbul was occupied by enemies of the religion. Moscow, the heritor of Istanbul and the capital city of the Tzar who is a sacred ruler of the whole Russia and the Christianity is the third Rome. There would be no fourth Rome. Because, firstly, the Moscow Tzar was appointed as the ruler of the whole world and the head of Christianity forever. Today, he is the only ruler of the Orthodox church.' (Ahmad, 2006, p. 162). Considering that such sources are not given in the Russian and Soviet literary criticism, the bringing of this point of view to the science by the researcher is quite interesting. 
At the 'Russian literature before Karamzin's stage, the researcher describes in detail the issues of becoming of the literary-cultural relations with Kiev City and Europe more useful, religious struggles and the translation of Torah and Bible, and reviews the works of such personalities as Lomonosov, Sumarokov, Derjavin, Fonvizin and Radishev. According to the researcher, the importance of this period is in the facts that the Russian literature got rid of the immitation and 'then, bringing of the essence of opposition to the idealism forming the foundation of the Russian literature.' (Samed, 2008, p. 166). It is also attractive that the researcher draws the attention to the fact that Russian writers and poets who used until that time to search for prominence by taking most of their subjects from the ancient time and in particular, through writing eulogies and odes started to analyze, research and describe real life events individually exactly from that period. According to the researcher, the key role in the change of the Russian literature in this direction belonged to encyclopedists, i.e. French enlighteners and the French Revolution. At the same time, such features as 'the getting rid of the literature from the reputation of the religion fully', 'getting of it an independent and worthy direction', and the partly elimination of 'the difference between the written language and the live language' in the prose literature are also mentioned for this period.

The researcher exploring the literal development as a historical process emphasises the importance of the 'Karamsin Period', and assesses Karamsin's literary activity as the key achievement of the time before Pushkin, and mentions this period as the transfer stage to the next development. The researcher does not also forget to mention the limited and controversial aspects in Karamsin's works, in particular, his negative attitude to the French Revolution, and criticizes his acting as 'a panslavism forerunner'.

One of the best chapters of the work 'General Characteristics of Russsian Literature is 'the time of Pushkin'. Finding it logical that historians of Russian literature start the history of the national literature from Pushkin, A.Aghaoglu tries to explain Pushkin's life, time, environment and works to the Turkish literary and scientific worlds in a small research work. The researcher concludes that the works that Pushkin wrote at the first stage of his literary activity were influenced by Italian poet Ariston, English poet Byron and sometimes Shatabrion, and emphasizes that it is a new stage in terms of language. When mentioning the influence of Byron to the poet, he emphasizes the characteristics of Byronism and analyzes the works of Pushkin and Byron based on various examples. Attaching importance to the fact that romanticism had a new essence in Pushkin's works, the researcher wrote: 'This renaissance originating from Pushkin forms this opinion that the disease of Byronism originated from egoism. While avoiding from culture, 
Byron's characters become a capture of their personal dreams and passion more than thinking about the interest of the society. They want to make their personality superior and become dominant in their environment. Finally, Pushkin describes Byron as a 'proud poet'. And after this renaissance, romanticism got a different form and essence in Pushkin's works: The poet gave a hug to the Russian life and Russian history, and besides getting his subjects from there, he also searched for inspiration and found it there.' (Ahmad, 1989, p. 185).

So, besides reviewing the path of historical development of the Russian literature in his work titled 'General Characteristics of Russian Literature', A.Aghaoglu gives detailed information about the general stages, periods, nature and various personalities of this development path. However, this research work cannot be only regarded as an informative work, as it conducts a wide research, makes some references to Russian literary critics and makes some conclusions from the points of view of literary criticism and literary study. If we considered that this work was written in the literary environment of Turkey and it was the product of the period when the author was a teacher of Istanbul University, then the nature and essence of the research would also become clear. However, if we consider from the point of view of the history study of Azerbaijani literature, we can see that there are many novelties in the research. For example, when this work was written, only some literary and critical articles of F.Kocharli were available in the literary criticism of Azerbaijan. However, in these articles of F.Kocharli, the detailed analyzes specific for the works of A.Aghaoglu are not visible significantly. We can think that the being of A.Aghaoglu's research object the Russian literature and conduction of some researches in this regard before him enabled the author to express his opinion perfectly from the scientific-theoretical point of view. Intending exclusively these factors, academician K.Talibzadeh mentioned that there was more conformity between Abdullah Sur's history of literature and wrote: 'General Characteristics of Russian Literature' notably differs from those before it as the history of literature. Unlike the literary history of F.Kocharli, it analyzes the literary-historical process by periods and stages. The literary movement is summarized and literary events are highlighted in a close relationship with the social-political life. Surely, in this respect, there is closeness and conformity between Abdullah Sur's work 'Review of Turkish Literature', of which some drafts are available, and the 'General Characteristics of Russian Literature' in terms of both the structure and analysis method. However, since A.Aghaoglu had set a different goal for him, he did not use portrait essays and tried to determine the positions of personalities within the literary process' (Kamal, 1989, p. 145).

Certainly, A. Aghaoglu's research has chosen both the modern and the most difficult path to literary history. During that period, such a method of analysis of 
literature was not fully formed in Azerbaijani literature. In this analysis, literary movement is shown in full development, general features of Russian literature are being revealed. It stemmed above all from this fact that A. Aghaoglu succeeded in analyzing the literary development theoretically, conveying his thoughts through generalizations and comparisons, because he was one of the new generation critics and researchers. On the other hand, because the research was about Russian literature, possibly, the author had some resources at his hand. As F. Kocharli's literary history was the first, probably, these types of generalized, comparative analyses were very few. He had used personal archives, manuscripts much more. Although K. Talibzade has highly-appreciated his work "General characteristics of the Russian literature", the researcher was cautious about his personality and outlook. In this article which was written in the late 80s - on the eve of the collapse of the Soviet Union, the author's still an ideological approach to his creativity can be explained by only the existence of administrative fear that once surrounded the Soviet government. That's why when evaluating the articles A. Aghaoglu wrote about the Western literature in the early XX century, the author doesn't forget to mention the "bourgeois nihilism" either: "Nevertheless, the general spirit of the article shows that the purpose of the author is not limited to the use of pearls of world literature. He uses this opportunity to express his theoretical views on contemporary literature. The critic who forgets the principle of objective historicism opposes European literature against national literature. He cannot evaluate the new, positive qualities of Azerbaijani literature. Thus, descending to the level of bourgeois nihilism A. Aghaoglu approaches a new development of modern national literature with the criteria of classical Western masterpieces and does not find a single work that will satisfy his own artistic value. (Kamal, 1989, p. 139). But actually, the main purpose of A. Aghaoglu was not to make a comparison between Western and Azerbaijani literature, and as the occasion arises, he had also appealed to our national literature.

\section{Analising the cultural in the work "Three cultures"}

A. Aghaoglu's work on "Three Cultures" analyzed many problems, namely, the concepts of culture, state, religion, morality, society, individual, family and society, and introduced new concepts, the answer for the question "What is culture?" was searched, and determined the common point between "Islamic culture" and "Western culture", and "winning and losing" cultures. But in the context of the culture, the work also discusses literature. The writer also touches upon the literature while discussing the ethical problem in cultures. According to him, before the advent of the jurisdiction, there was no moral discipline not only in 
madrasahs but also in other schools. As is not the case in schools, it is difficult to find anything related to this subject in the field of literature and the press (Ahmad, 2006, p. 86). A. Aghaoglu attributed this to the lack of a strong current in our literature. According to him, we are behind Pascal of France and Leibniz of Germany in the field. He put forward that "Kalila and Dimna", which had been translated from existing Hindi to Persian and Arabic, Saadi Shirazi's "Gulustan" and "Bustan" did not satisfy our age from the essential point of view.

A. Aghaoglu dwelled on Oriental literature, especially Sheikh Saadi very much, and he came to the conclusion that the literary texts did not satisfy the new generation: "We have chosen Sheikh to be a perfect example. All of the writers who had written such works of ethics and nurture in our old literature took him as an example and tried to imitate him. They repeated the same principles with other words and more or less in a similar form" (Ahmad, 2007, p. 87). The author was not only a theoretical thinker of literature that had a special place in Oriental culture, but also compared this literature with Roman and Western literature and came to some conclusions. Widely focused on the influence of literature on social events, he appreciated the ideas of Western philosophers over society, recalling these philosophical tendencies in the writers' training. He also demonstrated the role of these trends in the widespread use of the "Tolstoyan movement" in Russia. Noting the importance of the schools and the university in the formation of all these, he said that the works of the First Peter had given its effect. 'He knew that after a while Russian would be the dominant language in the same academy and same university, and one day it would become one of the main languages of Europe by moving forward and rising every day. Really, just one generation later Russian scientists and writers like Lomonosov grew up. Two generations later, Pushkins and the Lermontovs gave the Russian language luminosity, sophistication and fluidity as much as the world's best languages' (Ahmad, 2006, p. 124).

A. Aghaoglu also touches upon the subject matter in the Oriental literature. He strongly criticized the poets of different ages in the Oriental literature for creating works in the same topics, as well as for portraying not the real life, but "groundless", "imaginary" people, and questioned the difference between Nizami's "Layla and Majnun" and Fuzuli's "Layla and Majnun". All of this has had an effect on the Muslim community, and literature has moved away from life. The idea that "Russian storm" made Tolstoys, Gorkies, referring to the experts' opinion that the XVIII century French literature had been created by French revolutions, clearly showed what he wanted from the literature. However, he drew attention to the fact that there had been some revival in Turkish literature after the Age of Regiment and exemplifies Namik Kemal's creativity. In his opinion, Namik Kemal brought literature to life, revived it in terms of themes and tendencies, arguing that 
literature was not fun, but rather a serious social factor. Drawing attention to the fact that literary matters had a special place in "The Three Cultures", Prof. V. Sultanli wrote: "As Aghaoglu evaluated the literature in his "Three Cultures" treaty from the point of combination of sociopolitical ideology with artistic and aesthetic capacity, he approached the literary process from this prism and appreciated the creativity of Turkish poet Namig Kamal” (Vaqif, 2006, pp. 13-14).

\section{Iran in Aghaoglu's work}

It is impossible not to mention the "Iranian and its revolution" that had a special place in A. Aghaoglu's creativity. This work was first published in 1934 in Ankara under the name of "Iran between 1500 and 1900". The second time it was included in the third volume of "Aghaoglu collection" in 1941. Giving an epigraph to the work Samad Aghaoglu who prepared the work for publishing, said: "I thought that if my father was alive he would have dedicated this work to the Turks, being Omar Naci in the first place, who had worked and given their life for the Iranian revolution and I tempted to do it on his behalf" (Samed, 2008, pp. 363-364).

The period in which the author focuses mostly on the work of "Iran and the Revolution" is the events of recent years. In this section, the writer touched mostly upon the events of the 1890s. He recommended reading two English-language works on Iran while providing information on the prerevolutionary Iran's governance and financial situation; one of them was the works of Sir Moryer who had been in the British Embassy in Iran, and the other one is the works of Lord Kerzon. The volume of both works is $700-800$ pages. According to the writer, the work of Moryer is translated by Shukru Gaya Bey. Lord Kerzon, the author of the second work, was an employee of the "Times" newspaper. He had also traveled to Iran after reviewing all the travel books previously written about Iran and come here, generating statistical data, history, geographical details, maps and schedules that would not be available anywhere in Iran. The book strongly criticized Shah's tax system, revenues, and expenditures. In particular, by revealing the king's revenues, it was clear how he had made his citizens make an expense. Author Kerzon also wrote about penalties imposed by the king. Kerzon also provided some examples of how these fines had been received. One of these examples is about a soldier cutting his carriage to file a complaint against the master, "Babi, the assassination!" after being stamped with the name, the king decrees that he be assassinated as an assassin. It was only later learned that the soldier had not been guilty. To correct the mistake, the king orders to give "bashar" to the family of murdered ones and the aide who had given him false information was fined about 
eight hundred thousand of tumen. However, it was not clear to the author why the fine given to the aide should be reached to the king, not the victim. In his work, Lord Kerzon described the justice system and the situation in the army in all its realities. He wrote about the justice system: "There are two types of judges and courts: the jury, the tribunal, and the civil courts.

Shariah laws were implemented by Mujahideen and mullahs and were generally used for crimes. The "eye for eye, nose for nose" method was used in the punishment. A Sheikh-ul-Islam was assigned to every big city. Mullah's verdicts would be sealed by Sheikh-ul-Islam and executed by governors" (Ahmed, 2009, p. 131).

While speaking about the reform and general pardon of Nasraddin shah during his reign, Aghaoglu emphasized his trip to Europe and said he had been to Europe three times. However, it was also noted that these visits did not produce anything important for Iran's reform. The author, who also reminded his presence in Paris during the centenary of the Revolution in 1889, personally observed his characters like pride, arrogance, egoism, and selfishness: "I was a student there when the King visited Paris. There was an air balloon in Paris on the occasion of the exhibition. The king got on this balloon and watched the city from above. When he landed there was a poet Hugo Leroux, a socialist MP. The poet, unable to restrain himself, said: 'Your Majesty, you have seen the blessings, works of the culture. By the time you return to Iran, we hope that the Aryan Iranians of our race will make use of these blessings.' The king ironically said: 'You are a poet. I am also a poet. Hope is food for poets. Hope!' On the second day, all the Paris newspapers mocked the poor French poet (Ahmed, 2009, p. 134)

A. Aghaoglu also focuses on the moral factors of the Iranian Revolution; he put forward that in the meantime, increased trade turnover with Europe, sending the children of the wealthy to the West for education, newly established schools in cities like Tehran, Tabriz, Isfahan, Shiraz, and more had taken an important place. At the same time, in the sources of the revolution, he showed the Iranians - Iranian Zoroastrians who had once migrated to India. These Iranians, who became the richest and most intelligent part of India, never broke up with their native land and they visited the ancient temples. Their newspaper in India "Hablulmatin" was widely read in Iran because of its reformist and revolutionary position. Considering this, Iranian officials have banned the newspaper, but the newspaper was brought to Iran unofficially and read.

A. Aghaoglu emphasized the Caucasus and Caucasus Azerbaijan too, as one of the factors that shaped the Iranian Revolution. He drew the attention to the impacts on 
Iran by this relationship between the two Azerbaijan, and by Caucasus Azeris who lived better and were more open-minded. The sociopolitical processes that took place in Azerbaijan in the late 19th and early 20th centuries do not exclude the influence of press agencies such as "Akinchi", "Hayat", "Fuyuzat" and "Irshad". Besides this, he also looks at the activities of the Ottoman Turkish revolutionaries in Iranian Azerbaijan. He cites the privileges granted to foreigners, among other factors, which, according to Professor Brown, provide ground for revolution. Writing that this was one of the factors, the author points out that during Nasreddin shah's reign the "monopoly on tobacco" privilege which had been given to a man named Talbot from English class, caused a great turmoil in the country. Actually, this privilege served to deprive the poor of their source of livelihood.

In "Iran and its revolution", the history of the revolution was also given a wide coverage; some matters like Iran shah's trust to the British and the Russian in this process, using their political and military power, especially the Russian intervention to revolutions with the help of army in many processes, etc. were described in details. This part of the work is so important because the reason for the revolution's defeat becomes clear here with all of its essences. The ways in which Muzaffaraddin shah, Mahammadali shah and Ahmad shah suppressed the revolt, curbed the feelings of freedom and independence, prevented the new governance system, were shown in facts.

\section{Conclusion}

A. Aghaoglu's works on literary criticism and the history of the Iranian Revolution, his ideas and his conclusions, once again prove that he is a researcher, literary and historian. The style of his works was scientific, and his analysis and results contained the scientific innovations of his time. With these works and meetings, he has brought an innovation in the literary and scientific environment of Turkey. All of her creativity is focused on community development and coincides with her practical work. In his writings, in his public and political activities, he was a reformer, objective, outspoken, intelligent man who worked for public affairs, preferred the citizenship above all, and played an important role in shaping this kind of intellectualism. 


\section{References}

Ahmad, A., (1989). Rus ədəbiyyatının ümumi səciyyələri (General Characteristics of Russian Literature). Azerbaijan magazine, Cild 1.

Ahmad, A., (2006). Üç mədəniyyət (Three Cultures). Baku: Mutarcim.

Ahmad, A., (2007). Seçilmiş əsərləri (Selected works). Baku: Sherq-Qerb.

Ahmed, A., (2009). İran və inqilabı (Iran and the Revolution). Baku: Azerneshr.

Kamal, T., (1989). Ahmad Aghaoglu. Azərbaycan (Azerbaijan), Cild 1.

Kamal, T., (1989). Ahmad Aghaoglu. Azərbaycan (Azerbaijan), Cild 1.

Samed, A., (2008). Hekayələr, memuarlar (Stories, memes). Baku: Ozan.

Vaqif, S., (2006). Ohməd Ağaoğlu fenomeni (Ahmad Aghaoglu phenomenon).

Baku: Three cultures.

Vilayet, G., (2007). Seçilmiş əsərləri (Ahmad Aghaoglu's Selected works). Baku: Sharq-Qarb. 